\title{
Factors Associated with the Communication Competence of Middle School Teacher to Gender Responsive
}

Ernita Arif*, Emeraldy Chatra

Andalas University, Padang, Indonesia

Article History

Received: 17.11 .2020

Accepted: 30.11 .2020

Published: 10.12.2020

Journal homepage:

https://www.easpublisher.com

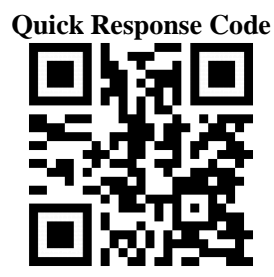

Abstract: The teacher has a strategic role in instilling the values of justice and gender equality $(\mathrm{KKG})$ in the learning process. These values can be socialized through behaviors that are exemplified by the teacher, because teacher behavior in the classroom has a great influence on children's mental development. A teacher is also asked to have gender responsive communication competencies, meaning that the teacher has good communication skills for male and female students. This study aims to identify factors related to gender responsive high school teacher communication competencies. The study was designed as a descriptive correlational survey. The study was conducted in Padang City and Agam District, West Sumatra Province. The study population consisted of teachers who taught in Padang City High School and Agam District. The number of samples was 100 teachers in Padang City and 100 people in Agam Regency using the Taro Yamane formula. The data collected in this study consisted of primary data and secondary data. Primary data collection was done using a questionnaire. Data analysis was carried out in descriptive statistics and Rank Spearman correlations. The process of data analysis using SPSS version 20 software. The results showed that there was a relationship between participating in communication training with gender responsive teacher communication competencies, there was a relationship between infrastructure availability and work atmosphere with gender responsive teacher communication competencies. This means that the factors related to gender responsive teacher competency are participating in communication training, availability of infrastructure and work atmosphere. For this reason, it is necessary to improve and maximize communication training activities and pay attention to the availability of infrastructure and work atmosphere.

Keywords: Communication competency, related factors, gender responsiveness, high school teacher.

Copyright (9) 2020 The Author(s): This is an open-access article distributed under the terms of the Creative Commons Attribution 4.0 International License (CC BY-NC 4.0) which permits unrestricted use, distribution, and reproduction in any medium for non-commercial use provided the original author and source are credited.

\section{INTRODUCTION}

Gender equality and justice (KKG) in various fields of life has become a global commitment including the Indonesian Government with the issuance of Presidential Instruction No. 9 of 2000 concerning gender mainstreaming (PUG) in national development which states that every government institution must implement gender mainstreaming (PUG) by integrating the dimensions of gender equality and justice in all stages of planning, implementing, monitoring, and evaluating and reporting development activities [1].

The KKG in the field of education, regulated by Law Number 20 of 2003 concerning the National Education System stipulates that the National Education System must ensure equal distribution and access to education, improve quality, relevance and competitiveness, as well as good governance, accountability and public image. Article 4 Paragraph (1) states that education is carried out in a democratic and equitable manner and is not discriminatory with high human rights, religious values, cultural values and national diversity. Article 5 Paragraph (1) stipulates that every citizen has the same rights to obtain quality education. Based on the legal basis, everyone has the same opportunity to obtain quality education in all types, levels and paths of education regardless of gender, socioeconomic status, religion or cultural background.

For this reason the Department of National Education (Ministry of National Education) issued Minister of National Education Regulation Number 84 of 2008 concerning Guidelines for Implementing PUG in the Field of Education. Article 1 states that each unit of work in the field of education that plans the implementation, monitoring and evaluation of all policies, and development programs in the field of education in order to integrate gender in it and Article 2 stipulates that every educational work unit proven to carry out PUG in education is not suitable with the 
provisions referred to in Article 1 given sanctions in accordance with the legislation.

Based from the above conditions, educators play a very strategic role to transfer the right knowledge about the values of gender equality and justice (KKG). KKG values are socialized by teachers through teacher and student interaction. Psychologically, students see the importance of the teacher's role. The child's trust in the things that the teacher says and does is very strong. Approval and refusal of teachers towards an action that a child does is an effective way to socialize the values of children. For children, the teacher is a model that will be an inspiration to imitate or identify.

The teacher has a strategic role in instilling the values of justice and gender equality (KKG) in the learning process. These values can be socialized through behavior exemplified by the teacher, because teacher behavior in the classroom has a large influence on children's mental development [2]. In line with the opinion of Ahmadi and Sholeh [3], teachers have a role in the development of students, especially at the primary education level, because at that level students tend to still imitate the teacher's speech and actions, both those seen and heard.

In addition to the serious attitude of the government to implement KKG in education. The basic thing is also from the aspect of the teacher, where the teacher must be the main pillar of gender meanstreaming, because gender is an ideology that is very visible in daily behavior and deeds. In school communities, which generally still adhere to a paternalistic culture, examples of gender fairness are very important. In such conditions, teachers must gain access to the basics of gender knowledge and education first, to provide an understanding of the problem. Because gender issues are a cultural issue, this gender education for teachers may not be carried out in a confrontational manner in a short period of time. If the teacher / educator have gained sufficient access to gender knowledge, then a very important commitment to be used as a basis for building gender education will be much more easily achieved [4].

But the reality is there are still teachers in the field who do not have or lack knowledge about gender, so that it will have implications for understanding the students between men and women. Teachers who are not gender sensitive will behave gender bias [5]. Based on previous research in West Sumatra Province conducted by Triana et al. [6] have proven that teacher treatment and textbooks have caused gender bias in education. Arif et al. [1] found that the factors related to gender responsive teacher communication behavior in elementary schools were; parents' work background, family status, cosmopolitan, gender construction, involvement in the learning process and work environment. For this reason the researcher is interested in researching related to factors related to school teacher communication competencies above gender responsiveness.

\section{ReSEARCH MethodS}

The study was designed as a descriptive correlational survey research that describes and explains teacher communication competencies in classroom learning carried out in Padang City and Agam District in West Sumatra Province. The study was conducted in Padang City and Agam District, West Sumatra Province, which was carried out from July to August 2018. The study population consisted of teachers who taught in Padang City High School and Agam District. The number of samples was 100 teachers in Padang City and 100 people in Agam Regency using the Taro Yamane formula. The selection and determination of respondents were carried out in stages (multi-stage random sampling). The data collected in this study consisted of primary data and secondary data. Collecting data in this study was preceded by secondary data collection, especially concerning theories related to research. Primary data is data taken directly from research subjects by conducting structured interviews and in-depth interviews with teachers using questionnaires. In the survey research, there were two research instruments used, namely questionnaires and in-depth interviews. Instruments in the form of questionnaires in the form of a closed questionnaire which includes gender responsive teacher communication competencies. All collected data are tabulated according to their categories, then analyzed according to research needs. Data analysis was carried out quantitatively with statistics. The data analysis process used SPSS 20 software.

\section{FINDINGS AND DisCUSSION Description of Research Location}

Education plays an important role in the development of an area, because education is closely related to the formation of human resources (HR). The government in this case through the education department of West Sumatra Province is very concerned about the aspect of education. The vision for the development of the education sector in West Sumatra Province is the realization of intelligent human resources in West Sumatra with a civilian character and competitiveness. Its mission is; (1) increase access and equity of secondary education, (2) improve the quality, relevance and competitiveness of secondary education and PKLK, (3) improve the management and accountability of education management, (4) improve the competence and professionalism of teachers and education personnel, (5) increasing the growth of character and character education through educational services, with the motto of working worship. At present the education office of the province of West Sumatra is led by Mr. Drs. Burhasman, MM. 
Research was conducted in two regions, Padang City and Kab. Agam. In general, the number of high schools in West Sumatra Province totaled 467 schools consisting of 307 public schools and 160 private schools. For the city of Padang, there are 60 high schools consisting of 20 countries and 43 private schools. The number of teachers is 1767 in 11 subdistricts. For in the Kab. Agam, the number of schools is 52 , consisting of 27 countries and 25 private, with the number of teachers as many as 878 scattered in 15 subdistricts.

\section{Characteristics of RESPONDENTS \\ Age}

Age is one of the social factors that affect human activities to fulfill the needs of everyday life. Age is one of the characteristics of a teacher that is very important to know. The results showed that the age of the teacher was divided into three categories: young, adult and old. From each category, it can be seen that the youth category is 28 percent, the adult category is 37 percent and the old category is 35 percent.

The results of the study show that the average age of the teacher is an adult or includes a productive age. Referring to the opinion of Rusli [7] which states that productive age ranges from 15 years to 65 years which allows someone to learn. The data above indicates that teachers are allowed to continue learning because their age is in the productive range.

\section{Formal education}

Education is very important in the development of human resources, because education will have implications for knowledge, attitudes, and skills in dealing with life and various problems. Education in this study is measured based on the level of education taken by high school teachers in formal education.

The results of the study show that the level of formal education of teachers is generally highly educated (undergraduate) seen from the level of education of highly educated teachers as much as 100 percent. This shows that the compulsory undergraduate teacher and those already regulated in Law No. 14 of 2005 concerning teachers and lecturers that teachers are required to have academic qualifications obtained through higher education undergraduate programs or four diploma programs.

\section{Teaching time}

The teaching experience in this study was analyzed from the length of the teacher teaching in high school. The results of the study show that on average teachers already have long teaching experience. This can be seen from the teaching experience of teachers who are categorized as low (1-12 years) as much as 26 percent, medium category (13-24 years) as much as 44 percent, and classified as high (25-36 years) as much as 30 percent. Teaching experience is one of the factors in supporting the implementation of teaching and learning activities. Adequate teaching experience, in the sense that the time passed by a teacher in carrying out his duties will support the achievement of the goals set by the school.

Experience is closely related to one's ability, the more experienced the higher the ability possessed, in line with Malik's [8] research which found a positive relationship between teacher's teaching experience and teacher's ability. It is expected that teachers who have a lot of experience will increasingly have the ability to teach and face all the problems faced in the learning process.

\section{Cosmopolitan}

A cosmopolitan person is willing to seek new or open ideas for innovation, always engage in dialogue or communication that creates critical awareness, has high empathy skills so that it produces the right communication, has a high level of innovativeness, motivation, and aspirations, always experiencing changes in knowledge skills and attitudes towards the process of adopting an innovation.

The cosmopolitan level in this study was seen from the frequency of teachers traveling outside the region in the last six months such as visiting education offices, attending a whorkshop, attending training, seminars, attending teacher working groups (KKG), comparative studies, and visiting the library. In general, the teacher's cosmopolitan level is low. This can be seen from the low level of cosmopolitan (0-8 times) as much as 100 percent.

Based on observations and interviews with teachers and informants, the teacher's low level of cosmopolitanism due to a lack of opportunities to travel outside the region due to the teaching burden is the lack of activities that can encourage teachers to make outward visits. Although there is an irregular nature, this is told by an informant.

\section{Dependence on Mass Media}

In addition to the low level of teachers' cosmopolitan in terms of contact with outsiders other than the school environment, it turns out that teachers are also low in utilizing mass media such as newspapers, magazines, newspapers, television radio, and the internet. From the results of the study, it can be seen that the level of isolation is classified as low (0-33 minutes) as much as 88 percent, medium category (3467 minutes) as much as 12 percent. This means that in general teachers rarely read newspapers, magazines, newspapers, listen to the radio, watch television and access the internet. Judging from each activity, to read low category newspapers (0-33 minutes) as much as 100 percent, reading low category textbooks (0-33 minutes) as much as 20 percent, moderate categories 
(34-67 minutes) as much as 50 percent, categories high (68-101 minutes) as much as 30 percent. Read books outside the textbook; low category as much as 50 percent, medium category 35 percent and high category 15 percent. Reading magazines is categorized as low as 100 percent, as well as listening to the radio. To watch television in the low category as much as 20 percent, the medium category is 56 percent and the high category is 24 percent. Accessing the internet is categorized as low as 3 percent, medium category 30 percent and high category 67 percent. From the results of the study, it was seen that high school teachers were classified as high to access the internet. Different from the research results Arif et al. [1] found that elementary school teachers were low in accessing the internet.

\section{Engagement in the Learning Process}

Involvement in the learning process in this study was seen from the frequency of teachers participating in gender communication and training training. All indicators of involvement in the learning process are in the low category. The results of the study show that 75 percent of teachers have never attended communication training, as many as 17 percent are rare and only 8 percent often attend communication training. This means that a few teachers have attended communication training. This is in line with the results of Arif et al. [1] research finding that elementary school teachers are low in participating in communication training.

For indicators of following gender training, it is also generally low. The results of the study show that 78 percent of teachers have never participated in gender training, as many as 20 percent are rare and only 2 percent often attend gender training. This means that very few teachers have attended communication training. This is also in line with the results of Arif et al.
[1] study which found that elementary school teachers were low in attending gender training.

\section{Working environment}

The work environment is analyzed from the teacher's assessment of the availability of facilities and infrastructure, as well as the work atmosphere. The results showed that 76 percent of respondents had an assessment that the availability of facilities such as classrooms for male and female students, male and female teacher rooms, sports facilities and infrastructure for men and women, facilities for male worship male and female, canteen, and male and female toilets are generally well available. This indicates that schools and facilities are available.

For the work atmosphere indicator is also good category, it can be seen that 96 percent of respondents said that the working atmosphere is good, only 4 percent said that it was not good. This means that respondents feel a culture of mutual respect and respect between men and women, a culture of mutual help between men and women, a school award for the achievements of male teachers and female teachers, school attention to male teacher careers and female teacher. In general the teacher's work environment is good. This means that the availability of facilities and infrastructure as well as the work atmosphere is good so that the teacher feels comfortable in his work.

\section{Factors Related to Communication Competencies of Gender Responsive Teachers}

The variables in this study include age, level of education, teaching experience, cosmopolitanism, deprivation of the mass media, communication training, gender training, availability of infrastructure, and work atmosphere. These variables will be correlated with gender responsive teacher communication competencies.

Table-1: Variables Relating to the High School Teachers' Communication Competencies in Gender

\begin{tabular}{|l|l|l|}
\hline \multicolumn{1}{|c|}{ Variables per Indicator } & $\begin{array}{l}\text { Correlation } \\
\text { Coefficient }\end{array}$ & $\begin{array}{l}\text { Gender responsive teacher } \\
\text { communication competence }\end{array}$ \\
\hline Age & $\mathrm{r}_{\mathrm{s}}$ & -.120 \\
\hline Education level & $\mathrm{r}_{\mathrm{s}}$ & .021 \\
\hline Teaching time & $\mathrm{r}_{\mathrm{s}}$ & .007 \\
\hline Cosmopolitan & $\mathrm{r}_{\mathrm{s}}$ & .108 \\
\hline Dependence on media & $\mathrm{r}_{\mathrm{s}}$ & .037 \\
\hline Follow communication training & $\mathrm{r}_{\mathrm{s}}$ &, $259^{* *}$ \\
\hline Follow gender training & $\mathrm{r}_{\mathrm{s}}$ & .030 \\
\hline Availability of infrastructure & $\mathrm{r}_{\mathrm{s}}$ &, $179^{*}$ \\
\hline Work atmosphere & $\mathrm{r}_{\mathrm{s}}$ &, $492^{* *}$ \\
\hline
\end{tabular}

PS: * Relates significantly to $(\mathrm{p}<0.05) * *$ Relating is very real in $(\mathrm{p}<0.01)$

$\mathrm{rs}=$ Spearman rank correlation, $\mathrm{C}=$ contingency coefficient

The results showed that age and level of education did not have a significant relationship with gender responsive teacher communication competencies. It can be said that the age and education level of a teacher has nothing to do with teacher communication skills both verbal and non-verbal to male and female students.

Teacher teaching experience does not have a significant relationship with gender responsive teacher 
communication competencies. It can be said that many and long teaching experiences possessed by a teacher have nothing to do with teacher communication skills both verbal and non-verbal to male and female students. The level of cosmopolitanism and isolation towards the media also does not have a very significant relationship with gender responsive teacher communication competencies.

Engagement in the learning process has a very significant relationship with gender responsive teacher communication competencies. This means that the higher the involvement in the learning process, the teacher in terms of participating in communication training, the better the gender responsive communication competency, meaning that the teacher who follows the communication training will further increase the knowledge, attitudes, and skills of the teacher in communicating. The results of this study are in line with the research of Arif et al. [1]; Zlatić et al. [9].

The work environment has a very significant relationship with gender responsive teacher communication competencies. This means that the better the work environment, the better the communication competence of male students and female students. A good work environment referred to here is an environment that is supported or supported by the availability of good and adequate facilities and infrastructure and a conducive working atmosphere.

Based on the results of the study it can be described that teacher communication competence is still gender biased, meaning that in communicating teachers still have stereotypical views on students both male and female, the teacher unconsciously still places certain sexes unequally by giving different opportunities and treatment to student. This can be seen from the teacher's habits in determining the class leader, and the ceremony leader. In this case female students are not prioritized or given equal opportunities to be selected and elected leaders. Besides that the teacher also still shows impatience in educating which can be seen from the attitudes of teachers who use unfavorable words to students with the pretext of disciplining or changing student behavior.

Seeing that there are still treatments that are gender biased will become obstacles to realizing justice and gender equality in education that has been mandated by law. For this reason it is hoped that teachers can apply gender justice and equality in education so that every male and female student can develop the best potential of his human resources. Teachers should not have a stereotypical view of male and female students which is an inhibiting factor in realizing gender responsive education. In addition, the teacher should provide equal opportunities and opportunities for male and female students to become leaders both as class leaders and as ceremony leaders and not discriminate between students in granting picket assignments. The results of Arif et al. [1] show that elementary school teachers still distinguish male and female students in determining class leaders, leaders of ceremonies and sports selection. This means that from elementary to high school level teachers still provide different treatment and opportunities for male and female students.

\section{For this reason the teacher should pay attention to the following}

1. Encourage class participation. In this case the teacher gives attention to all students both male and female. The teacher must be able to recognize each individual so that all class members can participate in the learning process.

2. Provide continuous motivation for male and female students that each individual has the same opportunities and opportunities to develop and excel.

3. Providing opportunities for every student, both male and female, to become a leader in this matter to be class leader, ceremony leader, team leader, and group leader.

4. Providing tasks that are more varied and not monotonous to male and female students, for example male students are also asked to be able to sweep, clean up classes, and vice versa female students can also do physical work such as lifting tables, taking water and remove the blackboard.

5. Providing opportunities for students, especially female students, to do sports and dexterity such as playing football.

6. Encourage students to be able to group and make groups as a vehicle to be able to develop the potential of each individual. The teacher only gives direction and motivation that each individual has the potential that will be a potential resource for the group.

7. Be careful with negative words like words that are degrading because they can weaken students' motivation to progress and excel. Teachers should increase positive words to male and female students, Karen this will increase student confidence.

\section{CONCLUSION}

The conclusion of this study is that the factors associated with gender responsive teacher communication competence are involvement in the learning process in this case participating in communication training, as well as the work environment. Whereas age, level of education, teaching experience, cosmopolitanity and media isolation were not significantly associated with high school teacher gender communication competency.

\section{REFERENCE}

1. Arif, E., Hubeis, A. V. S., Ginting, B., Purnaningsih, N., \& Saleh, A. (2014). Gender- 
responsive in Class: Study of Communication Behavior Teacher in Elementary School. International Journal of Humanities and Social Science, 4.

2. Danim, S., \& Khairil, H. (2010). Profesi kependidikan. Bandung: Alfabeta.

3. Sholeh, M., \& Ahmadi, A. (2005). Psikologi perkembangan. Jakarta: PT Rineka Cipta.

4. Tholkhah, I., \& Barizi, A. (2004). Membuka jendela pendidikan: mengurai akar tradisi dan integrasi keilmuwan [ie keiluan] pendidikan Islam. Divisi Buku Perguruan TInggi, RajaGrafindo Persada.

5. Cushman, P. (2010). Male primary school teachers: Helping or hindering a move to gender equity?. Teaching and Teacher Education, 26(5), 1211-1218.

6. Triana-Toribio, N., \& Toribio-Triana, N. (2003). Spanish national cinema. Psychology Press.

7. Rusli, G. A. (1995). Amaratunga, and SRP Silva. Thin Solid Films, 270, 160.

8. Neuman, W. (2006). Social Research Methods: Qualitative and Quantitative Approach. USA: University of Wisconsin.

9. Zlatić, L., Bjekić, D., Marinković, S., \& Bojović, M. (2014). Development of teacher communication competence. Procedia-Social and Behavioral Sciences, 116, 606-610. 